\title{
Evaluation of Water Quality of the Titas River Using NSF Water Quality Index
}

\author{
S. Islam ${ }^{1 \#}$, M. T. Rasul ${ }^{1}$, M. J. B. Alam², and M. A. Haque ${ }^{2}$ \\ ${ }^{1}$ Department of Civil Engineering, IUBAT - International University of Business Agriculture and \\ Technology, Uttara Model Town, Dhaka-1230, Bangladesh \\ ${ }^{2}$ Department of Civil and Environmental Engineering, Shahjalal University of Science and \\ Technology, Sylhet-3114, Bangladesh
}

Received 27 September 2010, accepted in final revised form 11 November 2010

\begin{abstract}
The Titas River, a trans-boundary river of Bangladesh flows almost the entire Brahmanbaria district, consumes a huge amount of sewage, agricultural discharges and runoff, waste produced from human excreta, discharges of two oil mills and contaminants from other minor sources. A study is conducted to find the water quality status of the river during the period from July 2008 to June 2009 and by using National Sanitation Foundation (NSF) water quality index, the probable use of this water is predicted. This work consists of laboratory tests for the evaluation of some water quality parameters of the Titas and to identify its probable use in various purposes. The results of the laboratory tests and NSF water quality index suggest that the water can be used for recreation, pisciculture and irrigation purposes but requires treatment before using for drinking.
\end{abstract}

Keywords: Water pollution; Faecal coliform; Dissolved oxygen (DO); Biochemical oxygen demand (BOD).

(C) 2011 JSR Publications. ISSN: 2070-0237 (Print); 2070-0245 (Online). All rights reserved.

doi:10.3329/jsr.v3i1.6170 J. Sci. Res. 3 (1), 151-159 (2011)

\section{Introduction}

Water is the fluid of life not only for human beings but also for any living organism. Oceans and seas are the main sources of water but they are not useable in most of the cases. The fresh liquid water sources on land surfaces and in the ground constitute only $1 \%$ of the total water on earth. The main sources of water in Bangladesh are surface waters in rivers, reservoirs, lakes, canals and ponds, and the ground water in deep and shallow aquifers [1]. In the ground water, presence of arsenic and iron are excessive almost all over Bangladesh. The rivers, main source of surface water, are also polluted day by day. Most of the big cities and settlements have developed near the rivers and

\footnotetext{
\# Corresponding author: sharif_sust_cee@yahoo.com
} 
urbanization becomes the main reason for pollution for these rivers and other water bodies [2]. The study by Hossain [3] showed that surface water quality of the rivers of the country had been deteriorating further and further due to continuous pollution.

The concept of water quality is fundamental to the study of environmental engineering and water resources because they explore the relation between water requirements and the form and extent of permissible departure from purity. This is inextricably linked with the term pollutants/ pollutions. A substance (either natural or man-made) becomes a pollutant only when it is introduced at a level or in a form that upsets the normal functioning of an ecosystem, or that affects human or animal health.

The Titas (also known as Haora) River originates from the hills of Tripura State in India. Flowing west near Agartala (India), the Titas enters Bangladesh through Akhaura and falls into the Meghna river south of Ashuganj (location: latitude: $23^{\circ} 51^{\prime} 43 \mathrm{~N}$ and longitude: $90^{\circ} 49^{\prime} 58 \mathrm{E}$ ). One of the offshoots of the Meghna River is also named as the Titas which branches out from the Meghna at Chatlapur and again meets the Meghna at Nabinagar in Brahmanbaria district. The total length of the river is about $98 \mathrm{~km}$. The map of our study area is shown in Fig. 1.

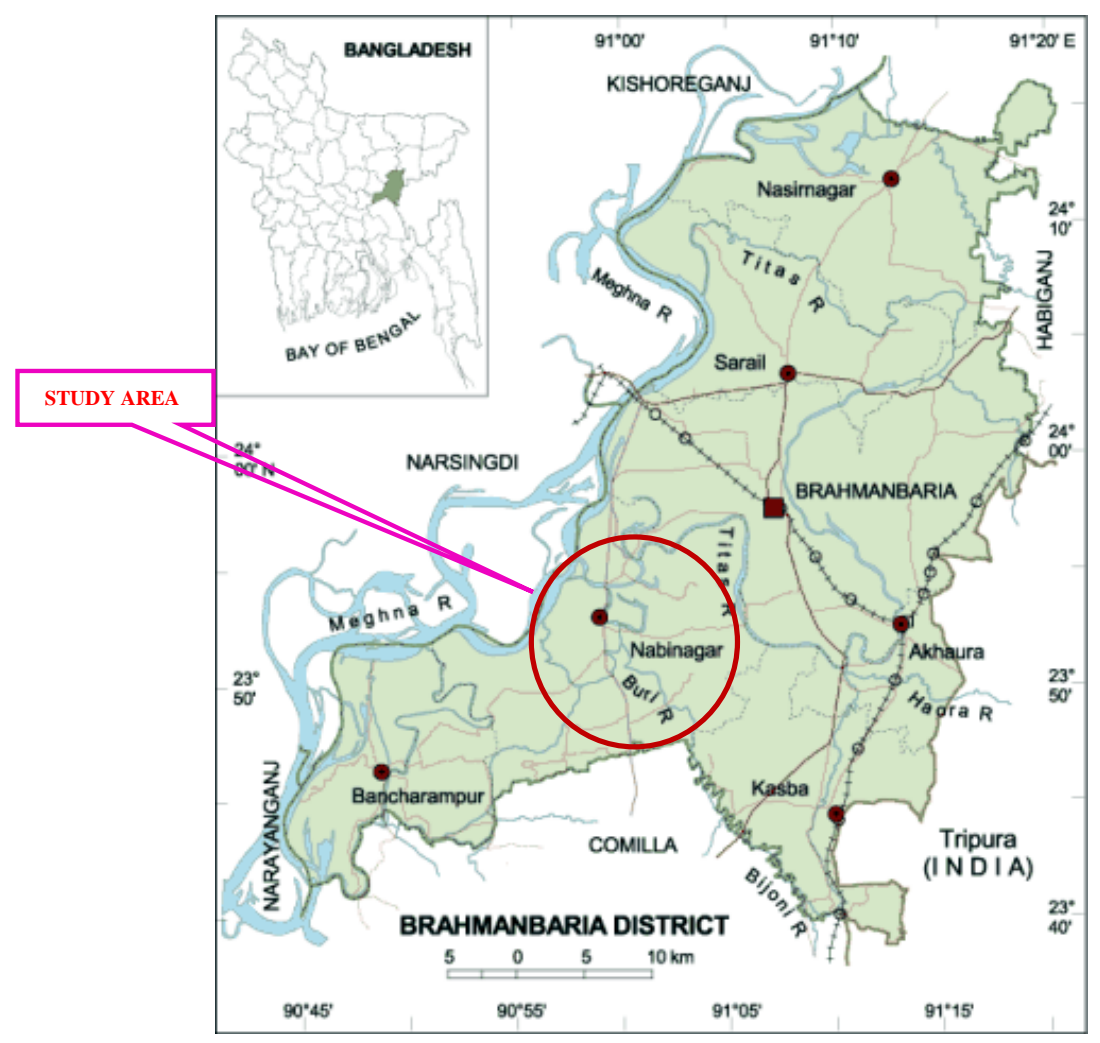

Fig. 1. Map of the study area. 
There is no big city developed on the bank of this river. The animal wastes, run off water from croplands and households, hanging latrines beside the river and forest floors are potential pollutants when they enter into the Titas River. In order to identify whether the river is polluted or not, the chemical, physical and biological conditions of the river must be analyzed.

Natural waste products, sewage and many forms of organic wastes are broken down naturally by microorganisms and are converted into such forms that are useful to aquatic life. When the ability of the river to dissolve, disperse and recycle such materials is exceeded those materials actually pose problems.

In Bangladesh, the rural and urban poor comprising $23.7 \%$ of the population practice open defecation and 37.5\% use hanging latrines [4]. Hanging latrines constructed by the side of rivers and other water bodies cause severe water pollution. The septic tank effluent, bucket latrine wastes and wastes of oil mills are being discharged into the water bodies of the Titas River which may have detrimental effects on water courses. Also, the pesticides and insecticides used in agricultural lands degrade the river water quality.

The NSF water quality index (WQI) was developed by the National Sanitation Foundation (NSF) in 1970 [5]. A total of 142 water quality scientists were interviewed regarding 35 types of water quality tests and asked to consider the appropriate tests to incorporate in the index. Nine water quality parameters were selected to include in the index. These parameters are as dissolved oxygen (DO), faecal coliform (FC), pH, biochemical oxygen demand $\left(\mathrm{BOD}_{5}\right)$, temperature change $(\Delta \mathrm{T})$, total phosphate $\left(\mathrm{PO}_{4}\right)$, nitrate $\left(\mathrm{NO}_{3}\right)$, turbidity $(\mathrm{T})$ and total solids (TS) [5, 6].

The water quality index relates the water quality parameters to a scale ranging from 0 (worst) to 100 (best) [5]. Based on water quality index the classification of water is shown in Table 1.

Table 1. Classification of river water based on water quality index.

\begin{tabular}{lccccc}
\hline WQI & $0-25$ & $25-50$ & $50-70$ & $70-90$ & $90-100$ \\
\hline Water Class & Very bad & Bad & Medium & Good & Excellent \\
\hline
\end{tabular}

Source: [5]

The Department of Environment (DoE), Malaysia has classified the river water as very polluted (WQI: 0-59), slightly polluted (WQI: 60-80) and clean (WQI: 81-100) based on water quality index. They have also categorized the water in five classes on the basis of WQI: Class I (WQI: >92.7), Class II (WQI: 76.5-92.7), Class III (WQI: 51.9-76.5), Class IV (WQI: 31-51.9) and Class V (WQI: <31) [7, 8]. The uses of different classes of water are shown in Table 2. 
Table 2. Uses of different classes of water.

\begin{tabular}{|c|c|}
\hline Class & Uses \\
\hline I & $\begin{array}{l}\text { Conservation of natural environment. } \\
\text { Water supply I - practically no treatment necessary. } \\
\text { Fishery I - very sensitive aquatic species. }\end{array}$ \\
\hline IIA & $\begin{array}{l}\text { Water supply II - Conventional treatment required. } \\
\text { Fishery II - sensitive aquatic species. }\end{array}$ \\
\hline IIB & Recreational use with body contact. \\
\hline III & $\begin{array}{l}\text { Water supply III - extensive treatment required. } \\
\text { Fishery III - common, of economic value and } \\
\text { tolerant species; livestock drinking. }\end{array}$ \\
\hline IV & Irrigation \\
\hline $\mathrm{V}$ & None of the above. \\
\hline
\end{tabular}

The main objective of the WQI system is to use it as a preliminary means of assessment of a water body for compliance with the standards adopted for five designated classes, mentioned above, of beneficial uses.

Environmental protection agency (EPA) defines comprehensive sets of determinants (water quality parameters) to monitor water quality which is particularly important in reporting status of river water [9]. Internationally, there are number of attempts taken to produce a method that meaningfully integrates the data sets and interprets them into simplified quantitative information for easy understanding [10]. In the United States National Sanitation Foundation (NSF) guides for defining water quality with Water Quality Index (WQI). It is a weighted linear system of products with the sub indices of individual parameter and a weighted value [11]. This study attempts to express the values of the water quality parameters by a simple number (NSF water quality index) which will be understandable by the general people of the country.

\section{Methodology}

The water samples were collected both in wet and dry seasons from ten locations maintaining a distance of 2 to $3 \mathrm{~km}$ from each other. This study has covered approximately 22-26 km linear distance near Nabinagar Upazila where Station-1 is at downstream and Station-10 at upstream.

The concentrations of river water quality parameter were determined in the laboratory and some tests in the field ( $\mathrm{pH}$ and temperature). $\mathrm{DO}, \mathrm{BOD}_{5}, \mathrm{PO}_{4}, \mathrm{NO}_{3}, \mathrm{FC}$ and TS of river water were determined following standard procedure (APHA-AWWA-WPCF 1989) [12] and $\mathrm{pH}$, temperature and turbidity were measured by $\mathrm{pH}$ meter, thermometer and turbidity meter respectively. The values of water quality parameters tested were 
compared with Bangladesh drinking water quality standard and in some cases with inland surface water quality for recreation, pisciculture and irrigation to observe the quality of the river water [13].

An equation of NSF water quality index was found by using weighted factor of individual parameter and sub-index of each water quality parameter based on their respective testing values which can be found by water quality index calculator or water quality index curve of respective parameters. The water quality index of individual parameter was calculated from water quality index calculator used by Environmental Engineering and Earth Sciences, Center of Environmental Quality, Wilkes University. According to NSF water quality index, Eq. (1) was used for the calculation [14].

$$
\begin{aligned}
W Q I= & 0.17 I_{D O}+0.16 I_{F C}+0.11\left(I_{p H}+I_{B O D}\right)+0.10\left(I_{\triangle T}+I_{P O 4}+I_{N O 3}\right)+ \\
& 0.08 I_{T}+0.07 I_{T S}
\end{aligned}
$$

where $I$ is the water quality sub-index (subscripts as defined earlier).

The water quality index was determined by using the water quality index equation. To find the water quality index of individual parameter, the mathematical average of the concentration of all the location was taken. Using water quality index, some predictions were made for the uses of the water at different purposes.

\section{Data Analysis}

The river water quality parameters which are necessary for finding NSF water quality index, such as $\mathrm{DO}, \mathrm{FC}, \mathrm{pH}, \mathrm{BOD}_{5}$, temperature, $\mathrm{PO}_{4}, \mathrm{NO}_{3}$, turbidity and TS are analyzed and their values are presented in column charts (Figs. 2 to 10) along with their standard values for Bangladesh [13] (BDS = Bangladesh Drinking Water Quality Standard, R = Recreation, $\mathrm{P}=$ Pisciculture and $\mathrm{I}=$ Irrigation).

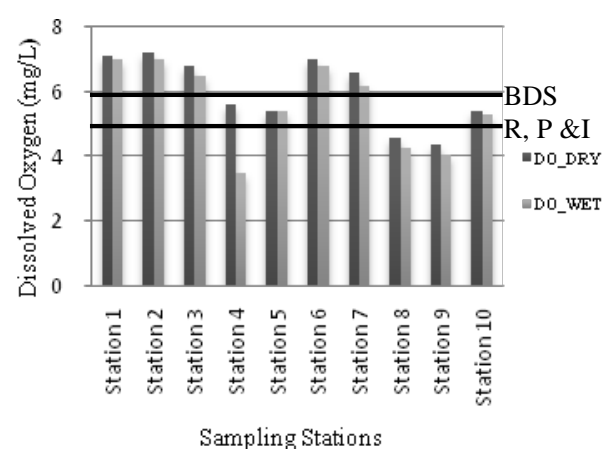

Fig. 2. Dissolved oxygen at different sampling stations.

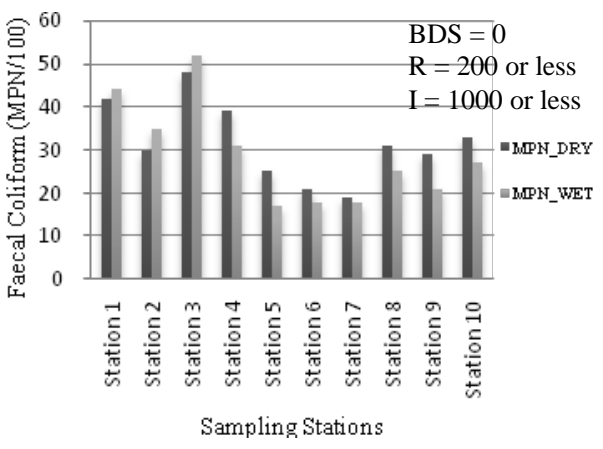

Fig. 3. Faecal coliform at different stations. 


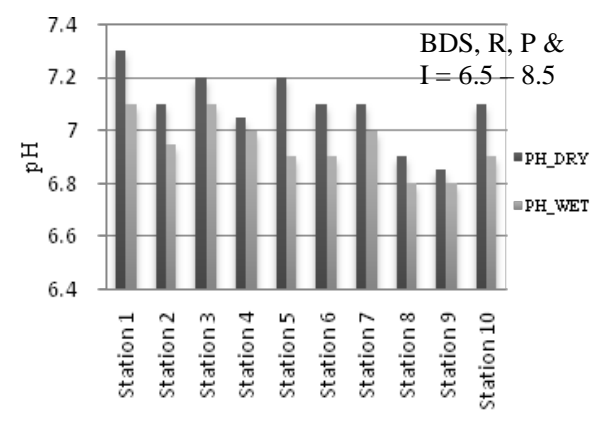

Sampling Stations

Fig. 4. $\mathrm{pH}$ at different sampling stations.

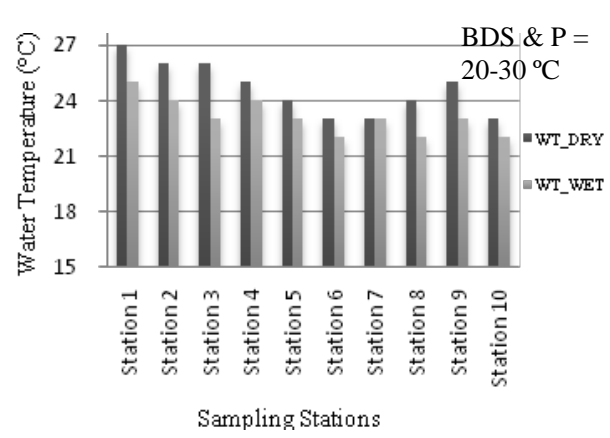

Fig. 6. Water temperature at different sampling stations.

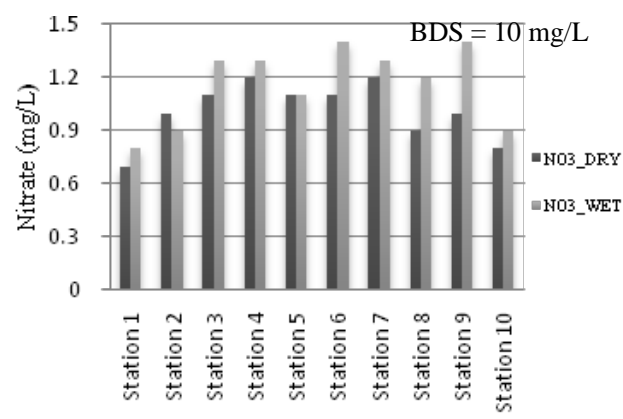

Sampling Stations

Fig. 8. Nitrate at different sampling stations.

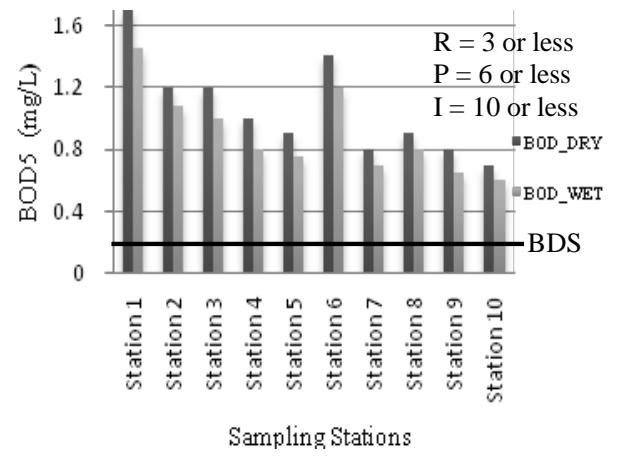

Fig. $5 . \mathrm{BOD}_{5}$ at different sampling stations.

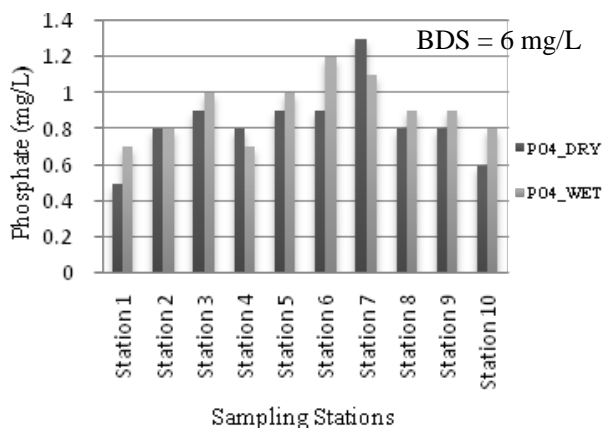

Fig. 7. Phosphate at different sampling stations.

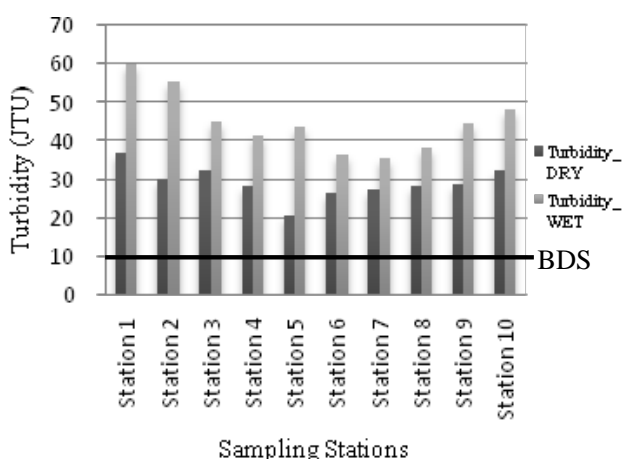

Fig. 9. Turbidity at different sampling stations. 


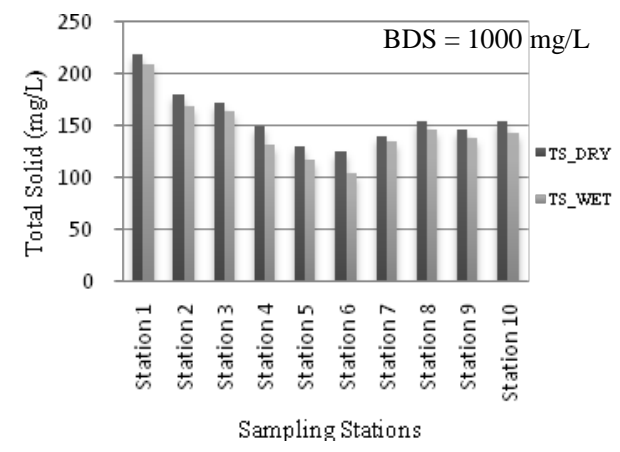

Fig. 10. Total solid at different sampling stations.

The average concentrations of all water quality parameters in both wet and dry season of nine water sampling stations are shown in Table 3 along with Bangladesh Water Quality Standard. Water quality index of individual parameter is calculated by water quality index calculator, shown in Table 3.

Table 3. Average concentrations of water quality and water quality index along Bangladesh water quality standards.

\begin{tabular}{|c|c|c|c|c|c|c|c|c|}
\hline \multirow[t]{2}{*}{ Parameters } & \multicolumn{4}{|c|}{$\begin{array}{l}\text { Bangladesh water quality standard } \\
\qquad \text { ECR } 1997 \text { [13] }\end{array}$} & \multicolumn{2}{|c|}{$\begin{array}{l}\text { Values of water } \\
\text { quality }\end{array}$} & \multicolumn{2}{|c|}{$\begin{array}{c}\text { Water quality } \\
\text { index (Unit less) }\end{array}$} \\
\hline & $\begin{array}{l}\text { Drinking } \\
\text { water }\end{array}$ & Recreation & Pisciculture & Irrigation & $\begin{array}{l}\text { Dry } \\
\text { season }\end{array}$ & $\begin{array}{l}\text { Wet } \\
\text { season }\end{array}$ & $\begin{array}{l}\text { Dry } \\
\text { season }\end{array}$ & $\begin{array}{l}\text { Wet } \\
\text { season }\end{array}$ \\
\hline DO (mg/L) & 6 & 5 or more & 5 or more & 5 or more & 6.01 & 5.61 & 5 & 5 \\
\hline $\begin{array}{l}\text { Faecal Coliform } \\
\text { (MPN/100) }\end{array}$ & 0 & 200 or less & - & 1000 or less & 32 & 29 & 58 & 59 \\
\hline $\mathrm{pH}$ & $6.5-8.5$ & $6.5-8.5$ & $6.5-8.5$ & $6.5-8.5$ & 7.09 & 6.945 & 90 & 87 \\
\hline BOD5 (mg/L) & 0.2 & 3 or less & 6 or less & 10 or less & 1.06 & 0.903 & 94 & 96 \\
\hline $\begin{array}{l}\text { Temperature } \\
\text { change }\left({ }^{\circ} \mathrm{C}\right)\end{array}$ & - & - & - & - & 1 & 1 & 89 & 89 \\
\hline Phosphate (mg/L) & 6 & - & - & - & 0.83 & 0.91 & 46 & 43 \\
\hline Nitrate (mg/L) & 10 & - & - & - & 1.01 & 1.16 & 96 & 96 \\
\hline Turbidity (JTU) & 10 & - & - & - & 29.3 & 45.01 & 54 & 42 \\
\hline $\begin{array}{l}\text { Total solid } \\
(\mathrm{mg} / \mathrm{L})\end{array}$ & 1000 & - & - & - & 157.4 & 146.3 & 78 & 79 \\
\hline
\end{tabular}

\section{Results and Discussion}

Putting water quality index of individual parameter in NSF water quality index equation, water quality index in dry and wet seasons are found to be 63.25 and 62.1, respectively. 
The maximum concentrations of different water quality parameters like faecal coliform, biochemical oxygen demand and turbidity has been found as $32 \mathrm{MPN} / 100 \mathrm{ml}$, $1.06 \mathrm{mg} / \mathrm{l}$, and 29.3 JTU, respectively which do not satisfy the Bangladesh drinking water quality standard but all other parameters satisfy the drinking standard. In case of drinking water, number of coliform bacteria must be zero [13]. The tested values of all parameters are in allowable limit for irrigation, pisciculture and recreational purposes though various discharges fall into the river.

Rasul and Jahan [15] studied water quality of the River Padma and obtained the average concentrations of $\mathrm{DO}, \mathrm{FC}, \mathrm{pH}, \mathrm{BOD}_{5}, \mathrm{PO}_{4}, \mathrm{NO}_{3}$ and $\mathrm{TS}$ as $7.83 \mathrm{mg} / \mathrm{L}$, 184/100ml, 7.67, $2.21 \mathrm{mg} / \mathrm{L}, 0.36 \mathrm{mg} / \mathrm{L}, 6.66 \mathrm{mg} / \mathrm{L}$ and $544 \mathrm{mg} / \mathrm{L}$, respectively. In case of $\mathrm{DO}, \mathrm{pH}$, and $\mathrm{PO}_{4}$, results of the present study are similar to the results of Rasul and Jahan [15]. But the results differ for the other parameters. The concentrations of FC, $\mathrm{BOD}_{5}$ and $\mathrm{NO}_{3}$ of the Titas are found to be less than those of the Padma. This indicates that the Titas is biologically less polluted than the Padma. In case of suspended solids there is a huge difference between the two rivers. The Padma water contains more solids than the Titas. Alam et.al. [16] analyzed the water quality of the Surma River. They found that the average concentrations of DO, FC, $\mathrm{pH}, \mathrm{BOD}_{5}$ and TS were $5.52 \mathrm{mg} / \mathrm{L}, 24.6 / 100 \mathrm{ml}, 6.13$, 1.00 and $285.0 \mathrm{mg} / \mathrm{L}$, respectively. All the testing concentrations of the Titas River are similar to those of the Surma River except for total solids (TS). The concentration of TS of the Titas River is approximately half of the Surma River.

Considering the variations in concentration of different parameters in both up and downstream, it has been found that most of the parameters change significantly at different stages except $\mathrm{DO}, \mathrm{PO}_{4}$ and $\mathrm{NO}_{3}$. The concentrations of FC, $\mathrm{pH}, \mathrm{BOD}$, temperature, turbidity and TS gradually increase in the downstream which indicates that pollution is increasing gradually towards downstream. The reason is obvious that more sources of pollution are being added to water as the river water flows downstream.

Based on water quality index, the water of this river can be classified as class III [7, 8] and the water quality is medium [5]. For public water supply system, this water requires necessary treatment. The water of the Titas River is fit for livestock, irrigation and fishery of tolerant species. It may be noted here that Salim et al. [17] studied the Gheshlagh River using water quality indices and found that the water of that river is fit only for agricultural purposes. In Bangladesh, the NSF water quality index system was not used before this study.

\section{Conclusion}

It is now clear from the analysis that the water quality of the Titas River is of medium category and belongs to Class-III based on NSF water quality index. It is not suitable for drinking but fit for other purposes like non sensitive pisciculture, livestock drinking, irrigation and recreation. Generally, once a trend in pollution sets in, it accelerates day by day. So, there is a possible risk of heavy water quality deterioration in near future. The proper authority should take necessary steps to maintain the acceptable water quality and 
ensure the flow of the Titas. Some steps could improve the river water quality like proper dredging, using pesticides and fertilizers in controlled manner, discharging domestic and industrial effluents after proper treatment and building up awareness about river pollution to the surrounding community.

\section{Acknowledgments}

The authors would like to record gratitude to Shahjalal University of Science and Technology, Sylhet, Bangladesh for providing the Laboratory facilities for this research.

\section{References}

1. M. F. Ahmed and M. M. Rahman, Water Supply and Sanitation: Rural and Low Income Urban Communities, $2^{\text {nd }}$ Ed. (ITN- Bangladesh, 2003).

2. DoE, The General over view of pollution status of Rivers of Bangladesh, Department of Environment, Dhaka, Bangladesh (2001).

3. A. Hossain, Evaluation of Surface water Quality: A case study on Surma River, B.Sc. Engineering Thesis, Civil and Environmental Engineering Department, Shahjalal University, Bangladesh (2001).

4. Bangladesh Bureau of Statistics (BBS): Statistical Yearbook of Bangladesh, 19th edition (1998).

5. R. M. Brown, N. I. McClelland, R.A. Deininger, and R.G. Tozer, Journal of Water and Sewage Works, 117, 339 (1970).

6. M. K. Mitchel and W. B. Stapp, Field Manual for Water Quality Monitoring, 12th Ed. (Kendall/Hunt Publishing, Dubuque, IA, 2000).

7. DoE WQS Phase 1 Study: Development of water Criteria and Standards for Malaysia Department of environment, Ministry of Science, Technology and the Environment, Kuala Lumpur Malaysia. 1986.

8. DoE WQS Phase 2 Study: Development of water Criteria and standards for Malaysia (Department of Environment, Ministry of Science, Technology and the Environment, Kuala Lumpur, 1990).

9. Framework for Community action in the field of water policy, Official Journal of European Communities, L 327, 1 (2000).

10. J. W. Nagels, R. J. Davies-Colley and D. G. Smith, J. Water Sci. Technol. 43 (5), 285 (2001).

11. W. D. Ashok and D. V. Raje, Fuzzy logic applications to environmental management systems: Case studies SIES-Indian Institute of Management, Nerul, Navi-Mumbai, India. Proc. of third world wide workshop for young environmental scientists (2000).

12. APHA-AWWA-WPCF, Standard methods for the examination of water and wastewater, (American Public Health Association, New York 1989).

13. ECR 97- The Environment Conservation Rule, Department of Environment, Bangladesh, Rule 12, Standards for Water, Schedule 3 (1997) pp. 205-207.

14. Environmental Engineering and Earth Sciences, Center of Environmental Quality, Wilkes University. http://www.water-research.net/watrqualindex/index.htm

15. M. T. Rasul and M. S. Jahan, J. Sci. Res. 2 (3), 577 (2010). doi:10.3329/jsr.v2i3.4093

16. J. B. Alam, A. Hossain, S. K. Khan, B. K. Banik, M. R. Islam. Z. Muyen, and M. H. Rahman, Environ. Monit. Assess. 134, 233 (2007). doi:10.1007/s10661-007-9612-7

17. B. J. Salim, G. N. Bidhendi, A. Salemi, M. Taheryioun, and M. Ardestan, Environ. Sciences 6 (4), 19 (2009). 